\title{
Perancangan Model VMI (Vendor Managed Inventory) dengan Satu Pemasok dan Banyak Retailer yang Meminimasi Ongkos Total Rantai Pasok
}

\author{
Yosefa ${ }^{1 *}$, Carles Sitompul ${ }^{2}$, Alfian ${ }^{3}$ \\ $1 *, 2,3)$ Fakultas Teknologi Industri, Jurusan Teknik Industri, \\ Universitas Katolik Parahyangan \\ Jl. Ciumbuleuit 94, Bandung 40141 \\ email : carles@unpar.ac.id, alfian.tan@gmail.com
}

\begin{abstract}
Abstrak
Persaingan bisnis yang terjadi antar perusahaan yang ada di negara maju semakin ketat seiring dengan pertumbuhan ekonomi yang terjadi di negara tersebut. Untuk memenangkan kompetisi, perusahaanperusahaan berlomba memperbaiki kinerja mereka. Salah satu cara yang dilakukan adalah menerapkan sistem persediaan barang yang lebih efisien yaitu dengan menerapkan manajemen supply chain yang akan memberikan keuntungan bagi pihak supplier maupun pihak retailer. VMI (Vendor Managed Inventory) merupakan salah satu metode dalam supply chain yang memberikan keuntungan bagi perusahaan melalui waktu replenishment yang singkat, perbaikan customer service level, total biaya rantai pasok yang lebih kecil dibanding metode persediaan tradisional. Penelitianpenelitian yang sudah dilakukan saat ini baru sebatas model VMI satu supplier dengan satu retailer. Padahal pada kenyataannya satu supplier dapat berhubungan dengan satu atau lebih retailer atau bahkan sebaliknya banyak supplier yang berhubungan dengan 1 retailer. Kondisi seperti ini menyebabkan perlunya pengembangan model yang melibatkan banyak retailer maupun supplier.

Dalam penelitian ini, dilakukan pengembangan model VMI yang dibatasi pada kondisi satu supplier dengan banyak retailer. Dilakukan penentuan parameter, variabel keputusan, fungsi tujuan dan koefisien pembatas untuk merancang model. Model yang dirancang kemudian diimplementasikan ke dalam bahasa pemrograman AMPL dan solusinya didapatkan dengan penggunaan software NEOS. Datadata yang digunakan merupakan data ilustrasi. Setelah didapat hasil dari pengimplementasian model, selanjutnya dibuat analisis berdasarkan hasil serta analisis sensitivitas untuk model. Hasil penggunaan model VMI (Vendor Managed Inventory) yang dirancang kemudian dibandingkan dengan hasil penggunaan metode lain, yaitu Q System serta WagnerWithin Algorithm.
\end{abstract}

Kata Kunci: Vendor Managed Inventory, satu pemasok banyak retailer

\section{Pendahuluan}

Seiring pertumbuhan ekonomi yang terjadi di negaranegara maju, persaingan bisnis yang terjadi antar perusahaan pun semakin ketat. Berbagai cara dilakukan untuk memperbaiki kinerjakinerja perusahaan guna memenangkan kompetisi antar perusahaan. Salah satu perbaikan yang dilakukan adalah mencari cara agar dapat menerapkan sistem persedian barang yang lebih efisien. Persediaan menjadi hal penting bagi perusahaan karena perusahaan tidak ingin

\footnotetext{
*Korespondensi Penulis
}

mengalami kerugian jika konsumen tidak jadi membeli barang karena barang tidak tersedia namun di sisi lain apabila perusahaan menyediakan barang dalam jumlah banyak, biaya persediaan yang dikeluarkan perusahaan akan semakin besar. Oleh karena itu, sistem persediaan menjadi salah satu hal penting yang harus diperhatikan oleh perusahaan.

Manajemen supply chain merupakan salah satu strategi yang dapat digunakan untuk mengatasi masalah pasokan barang. Menurut SimchiLevi dkk. (2000), strategi ini merupakan pendekatan yang digunakan untuk memastikan 
barang yang diproduksi dan didistribusikan berada dalam jumlah yang tepat, ke lokasi yang tepat dan waktu yang tepat untuk meminimasi biaya persediaan. Menurut Richardus Eko Indrajit dkk. (2002), supply chain sendiri merupakan sistem atau jaringan organisasi yang terhubung dengan berbagai macam proses dan kegiatan yang memberikan nilai pada produk dan jasa yang akan disalurkan dari produsen ke konsumen. Dalam manajemen supply chain terdapat hubungan antara pembeli dan penjual, dimana hubungan itu akan menguntungkan kedua belah pihak (winwin relationship). Hubungan tersebut biasanya disebut sebagai RSP (Retailer Supplier Partnership).

RSP merupakan strategi yang memerlukan kerjasama dan koordinasi yang baik antara pihak penjual dan pihak pembeli agar kedua belah pihak samasama mendapatkan keuntungan. Saat ini, ada tiga tipe RSP yang telah diterapkan dalam dunia industri, yaitu: QR (Quick Response), CR (Continuous Replenishment atau Rapid Replenishment) dan VMI (Vendor Managed Inventory). Penelitian ini hanya akan membahas mengenai VMI.

Menurut SimchiLevi dkk. (2000), VMI merupakan strategi yang memerlukan waktu replenishment singkat dengan frekuensi dan pengiriman yang tepat waktu sehingga dapat mengurangi biaya persediaan. Selain itu, VMI juga dapat memperbaiki customer service level yang akan meningkatkan keloyalan retailer terhadap supplier. Peningkatan customer service level terjadi karena supplier dapat memenuhi permintaan retailer tepat pada waktunya. Keunggulankeunggulan tersebut membuat VMI banyak diterapkan pada banyak perusahaan.

Dengan demikian, masalah yang dihadapi dalam penelitian ini dapat dirumuskan sebagai berikut: Bagaimana model VMI untuk satu pemasok dengan banyak retailer yang dapat meminimasi ongkos total.

\section{Tinjauan Pustaka}

Menurut SimchiLevi dkk. (2000), supply chain management adalah serangkaian pendekatan yang diterapkan untuk mengintegrasikan supplier, pengusaha, gudang (warehouse), dan tempat penyimpanan lainnya secara efisien sehingga produk dihasilkan dan didistribusikan dengan kuantitas yang tepat, lokasi tepat dan waktu yang tepat untuk memperkecil biaya dan memuaskan kebutuhan pelanggan.

Menurut SimchiLevi dkk. (2000), strategic alliance biasanya beragam, berorientasi pada tu- juan, kemitraan jangka panjang antara dua perusahaan dimana resiko dan keuntungan ditanggung bersama. Ada tiga macam strategic alliance menurut SimchiLevi dkk. (2000), yaitu :

\section{3PL (Third Party Logistics) \\ 2. RSP (Retailer Supplier Partnership) \\ 3. DI (Distributor Integration)}

Menurut SimchiLevi dkk. (2000), RSP (Retailer Supplier Partnership) adalah suatu strategi kolaborasi antara supplier dan buyer dimana dalam hubungan ini diperlukan kerjasama dan koordinasi yang baik antara kedua belah pihak untuk mendapatkan keuntungan yang dapat dirasakan bersama. Ada tiga tipe dari RSP, yaitu:

\section{QR (Quick Response)}

Pada QR, supplier menerima data POS dari retailer dan menggunakan informasi tersebut untuk disinkronkan dengan aktifitas produksi dan persediaan yang dimiliki retailer dengan penjualan pada retailer. Pada strategi ini, retailer masih mementingkan individual order, tetapi data POS digunakan oleh supplier untuk melakukan peramalan dan penjadwalan.

2. CR (Continuous Replenishment atau Rapid Replenishment)

Pada CR, vendor menerima data POS dan menggunakan data tersebut untuk mempersiapkan pengiriman dengan interval yang telah disepakati sebelumnya untuk mempertahankan tingkat persediaan.

3. VMI (Vendor Managed Inventory)

Pada VMI, supplier memiliki wewenang untuk menentukan order quantity yang akan dikirimkan ke retailer berdasarkan informasi data penjualan dan tingkat persediaan yang telah ditetapkan.

Ada dua langkah utama dalam mengimplementasikan VMI menurut SimchiLevi dkk. (2000), yaitu:

1. Ketentuan perjanjian kontrak harus dinegosiasikan. Dimana negosiasi tersebut termasuk keputusan mengenai kepemilikan, kapan barang akan dikirim, persyaratan kredit, tanggung jawab pemesanan dan ukuran performansi seperti tingkat layanan atau persediaan, jika diperlukan.

2. Ada tiga hal yang harus dieksekusi, yaitu:

(a) Mengembangkan sistem informasi yang terintegrasi untuk supplier dan retailer. Sistem informasi tersebut harus mudah diakses oleh kedua belah pihak. 
(b) Mengembangkan teknik peramalan yang efektif untuk digunakan oleh vendor dan retailer.

(c) Mengembangkan decision support tools untuk membantu dalam mengkoordinasikan kebijakan manajemen persediaan dan transportasi. Sistem yang dikembangkan tentu saja akan tergantung dari kemitraan.

Menurut SimchiLevi dkk. (2000), ada beberapa keuntungan yang bisa didapatkan jika menggunakan VMI, yaitu:

1. Supplier memiliki pengetahuan mengetahui order quantity dan kemampuan untuk mengontrol bullwhip effect.

2. Pada VMI, retailer akan memberikan informasi demand dan supplier akan membuat keputusan mengenai pemesanan yang akan mengontrol variasi dari order quantity. Hal ini dapat mengurangi biaya dalam sistem dan meningkatkan service levels. Supplier mendapatkan keuntungan dimana terjadi peningkatan service level, penurunan biaya manajerial dan penurunan biaya persediaan.

Menurut Tersine (1994), tujuan dari manajemen persediaan adalah memiliki jumlah persediaan yang tepat di tempat yang tepat, waktu yang tepat, dan biaya yang rendah. Biaya-biaya persediaan terdiri dari:

\section{Purchase cost}

Purchase cost merupakan biaya pembelian item, jika item tersebut didapatkan dari pihak di luar perusahaan. Jika item tersebut diproduksi sendiri oleh perusahaan maka purcahase cost merupakan biaya produksi item tersebut.

2. Setup cost

Setup cost adalah biaya yang dikeluarkan untuk melakukan pemesanan item ke supplier.

3. Holding cost

Holding cost adalah biaya penyimpanan dan perawatan item yang ada dalam persediaan. Biaya modal, pajak, dan asuransi merupakan contoh dari holding cost.

4. Stockout cost

Stockout terjadi apabila jumlah barang yang tersedia tidak dapat mencukupi demand konsumen.

Ada dua jenis sistem persediaan menurut Tersine (1994), yaitu: fixed order size system dan fixed order interval system. Tujuan utama dari kedua sistem persediaan tersebut adalah untuk menentukan jumlah barang optimal yang harus dipesan dan periode pemesanan optimal.

Fixed Order Size System, Continues Review System, atau Q System merupakan sistem persediaan yang harus terus menerus memonitori posisi inventory. Jika posisi inventory mencapai titik pemesanan kembali (reorder point) maka dilakukan pemesanan barang kepada supplier. Rumus yang digunakan adalah sebagai berikut:

$$
\begin{gathered}
Q^{*}=\sqrt{\frac{2 C R}{H}} \\
T C(Q)=P R+\frac{C R}{Q}+\frac{H Q}{2}
\end{gathered}
$$

dimana $Q^{*}$ adalah jumlah pemesanan optimal (unit), $C$ biaya pesan per sekali pesan, $\mathrm{R}$ adalah permintaan tahunan (unit), $\mathrm{H}$ adalah biaya simpan per unit per tahun, $\mathrm{P}$ adalah biaya beli per unit, dan TC(Q) adalah biaya total tahunan.

WagnerWithin Algorithm merupakan pendekatan pemrograman dinamis yang digunakan untuk menghasilkan perhitungan biaya optimal. Ada 3 langkah yang dilakukan dalam perhitungan ini, yaitu:

1. Menghitung matriks biaya total variable untuk seluruh alternative pemesanan yang dapat dilakukan selama N periode. Biaya total variable sudah mencakup biaya pemesanan dan biaya penyimpanan, dimana $Z_{c e}$ merupakan biaya total variable dari periode c hingga periode e yang memenuhi kebutuhan pada periode tersebut. Rumus yang digunakan sebagai berikut:

$$
Z_{c e}=C+H \sum_{i=c}^{e}\left(Q_{c e}-Q_{c i}\right)
$$

untuk $1 \leq \mathrm{c} \leq \mathrm{e} \leq \mathrm{N}$

$$
Q_{c e}=\sum_{k=c}^{e} R_{k}
$$

dimana $C$ adalah biaya pesan per sekali pesan, $\mathrm{H}$ adalah biaya simpan per unit per tahun, $R_{k}$ adalah tingkat permintaan pada periode $\mathrm{k}$.

2. Mendefinisikan $f_{e}$ sebagai biaya minimum yang dapat terjadi dari periode 1 hingga periode e, dimana tingkat persediaan pada akhir periode e adalah 0 . Algoritma dimulai dengan $f_{0}=0$ dan perhitungan $f_{1}, f_{2,}, f_{N}$ secara berturutturut. Perhitungan $f_{e}$ menggunakan rumus berikut:

$$
f_{e}=\operatorname{Min}\left(Z_{c e}+f_{c-1}\right)
$$


untuk $\mathrm{c}=1,2, \ldots, \mathrm{e}$

3. Untuk menerjemahkan solusi optimum $\left(f_{N}\right)$ yang diperoleh dari perhitungan algoritma menjadi jumlah pemesanan, diterapkan rumus berikut:

$$
\begin{gathered}
f_{N}=Z_{W N}+f_{w-1} \\
f_{w-1}=Z_{v w-1}+f_{v-1} \\
f_{u-1}=Z_{1 u-1}+f_{0}
\end{gathered}
$$

Pemesanan akhir dilakukan pada periode $\mathrm{w}$ untuk memenuhi permintaan dari periode w hingga periode N. Pemesanan sebelum terjadi pemesanan akhir dilakukan pada periode $\mathrm{v}$ untuk memenuhi permintaan periode $\mathrm{v}$ hingga periode $\mathrm{w}-1$. Pemesanan awal dilakukan pada periode 1 untuk memenuhi permintaan periode 1 hingga periode $\mathrm{u}-1$.

\section{Perancangan dan Pengujian Model VMI}

Kerangka pemodelan yang digunakan pada penelitian ini dapat dilihat pada Gambar 1, dimana huruf besar menyatakan pihak supplier sedangkan huruf kecil menyatakan pihak retailer. Notasi $Q$ dan q merupakan order quantity sedangkan $\mathrm{D}$ dan d merupakan permintaan (demand).

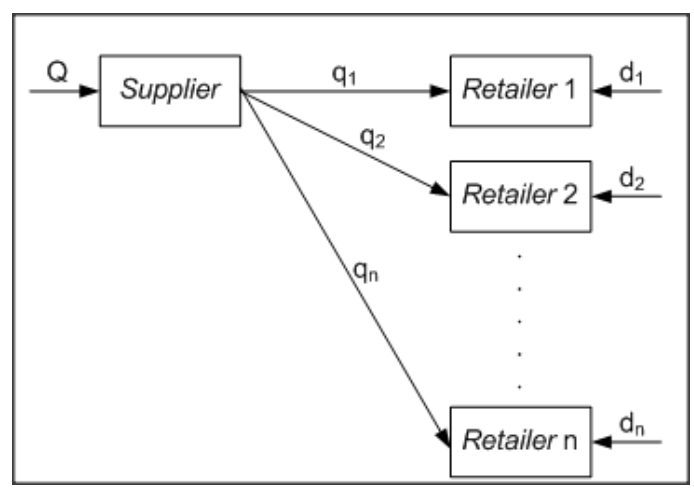

Gambar 1: Kerangka Pemodelan

Berdasarkan kerangka pemodelan tersebut diketahui bahwa demand yang terdapat pada supplier bersifat lumpy. Hal ini dikarenakan pada tiap periode supplier memiliki demand yang berbeda-beda. Contoh permintaan pada supplier yang mengirim pada 2 retailer dapat dilihat pada Gambar 2, dimana Frekuensi pemesanan retailer
1 adalah 3 kali dalam 1 tahun dan Frekuensi pemesanan retailer 2 adalah 2 kali dalam 1 tahun.

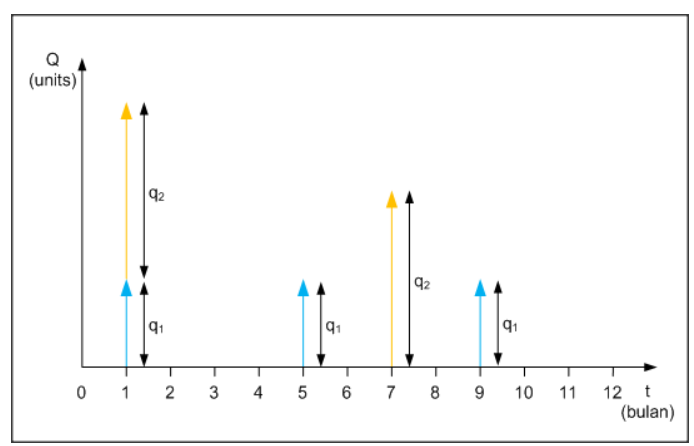

Gambar 2: Permintaan Supplier

Ada 3 metode yang digunakan untuk mendapatkan solusi kasus pada penelitian ini, yaitu: $Q$ System, WagnerWithin Algorithm, dan Model Optimasi yang merupakan model dari VMI untuk satu pemasok dan banyak retailer. Rumusrumus yang digunakan pada perhitungan Q System dapat dilihat pada (1) dan (2), sedangkan pada perhitungan WagnerWithin Algorithm menggunakan rumus $Q$ System pada retailer dan (3) hingga (8) pada supplier. Hal ini dikarenakan demand pada supplier yang bersifat lumpy sedangkan pada retailer tidak.

Rumus pada model yang dirancang, yaitu Model Optimasi dapat dilihat sebagai berikut:

$$
\begin{gathered}
\text { MinimasiT BRP }=\sum_{t=1}^{12} \frac{H}{12} \cdot P_{t}+\sum_{t=1}^{12} C . Y_{t}+ \\
\sum_{i=1}^{n} \sum_{t=1}^{12} \frac{h i}{12} \cdot P_{i t}+\sum_{i=1}^{n} \sum_{t=1}^{12} C i . Y_{i t}
\end{gathered}
$$

s.t.

$$
\begin{gathered}
P_{t}=P_{t-1}+Q_{t}-\sum_{i=1}^{n} q_{i t} \\
Q_{t} \leq M . Y_{t} \\
Q_{t} \leq M . Y_{t} \\
Y_{i t}=\left\{\begin{array}{cc}
0, & q_{i t}=0 \\
1, & q_{i t} \neq 0
\end{array}\right. \\
P_{t}, Q_{t}, P_{i t}, q_{i t} \geq 0
\end{gathered}
$$

dimana TBRP adalah total biaya rantai pasok, $\mathrm{t}$ adalah discrete period $(1,2,3, \ldots, 12), \mathrm{H}$ adalah biaya simpan supplier, $h_{i}$ adalah biaya simpan $r e-$ tailer i, $P_{t}$ adalah jumlah inventory supplier pada periode $\mathrm{t}, P_{(t-1)}$ adalah jumlah inventory supplier 
pada periode $\mathrm{t}-1, p_{i t}$ adalah jumlah inventory retailer i pada periode $\mathrm{t}, p_{(i t-1)}$ adalah jumlah inventory retailer i pada periode $\mathrm{t}-1, \mathrm{n}$ adalah jumlah retailer, $\mathrm{C}$ adalah biaya pesan supplier per sekali pesan, $c_{i}$ adalah biaya pesan retailer i per sekali pesan, $Y_{t}$ adalah keputusan pemesanan supplier pada periode $\mathrm{t}, y_{i t}$ adalah keputusan pengiriman retailer i pada periode t, $Q_{t}$ adalah jumlah pemesanan supplier pada periode $\mathrm{t}, q_{i t}$ adalah jumlah pengiriman retailer i pada periode $\mathrm{t}, \mathrm{M}$ adalah bilangan bulat besar, $d_{i}$ adalah jumlah permintaan retailer $i$.

Ada 10 studi kasus yang diuji pada penelitian ini. Datadatanya dapat dilihat pada Tabel 1. 6 studi kasus melibatkan 1 supplier dengan 2 retailer, 4 studi kasus melibatkan 1 supplier dengan 3 retailer.

Tabel 1: Rangkuman Soalsoal Studi Kasus

\begin{tabular}{|c|c|c|c|c|c|c|c|c|c|c|c|c|}
\hline \multirow{2}{*}{ Kasus } & \multicolumn{3}{|c|}{ Supplier } & \multicolumn{3}{|c|}{ Retailer 1 } & \multicolumn{3}{c|}{ Retailer 2 } & \multicolumn{3}{c|}{ Retailer 3 } \\
\cline { 2 - 14 } & $\mathrm{C}$ & $\mathrm{R}$ & $\mathrm{H}$ & $c_{1}$ & $d_{1}$ & $h_{1}$ & $c_{2}$ & $d_{2}$ & $h_{2}$ & $c_{3}$ & $d_{3}$ & $h_{3}$ \\
\hline 1 & 15 & 160 & 3 & 55 & 100 & 4.4 & 15 & 60 & 4.5 & 0 & 0 & 0 \\
\hline 2 & 25 & 180 & 2.5 & 50 & 80 & 5 & 30 & 100 & 9.6 & 0 & 0 & 0 \\
\hline 3 & 20 & 160 & 4 & 55 & 100 & 4.4 & 20 & 60 & 24 & 0 & 0 & 0 \\
\hline 4 & 7.5 & 180 & 3 & 15 & 60 & 4.5 & 12 & 120 & 3.2 & 0 & 0 & 0 \\
\hline 5 & 16.5 & 120 & 4.4 & 15 & 60 & 4.5 & 20 & 60 & 24 & 0 & 0 & 0 \\
\hline 6 & 15 & 240 & 4.5 & 12 & 120 & 3.2 & 20 & 120 & 12 & 0 & 0 & 0 \\
\hline 7 & 15 & 240 & 4.5 & 50 & 80 & 5 & 15 & 60 & 4.5 & 30 & 100 & 9.6 \\
\hline 8 & 15 & 240 & 4.5 & 60 & 120 & 4 & 15 & 60 & 4.5 & 20 & 60 & 24 \\
\hline 9 & 15 & 240 & 4.5 & 50 & 80 & 5 & 30 & 100 & 9.6 & 20 & 60 & 24 \\
\hline 10 & 15 & 240 & 4.5 & 15 & 60 & 4.5 & 12 & 120 & 3.2 & 20 & 60 & 24 \\
\hline
\end{tabular}

Tabel 1 menunjukkan rangkuman soalsoal studi kasus. Solusi untuk studi kasus tersebut menggunakan Q system, WagnerWithin Algorithm, dan Model Optimasi. Hasil perhitungan studi kasus dapat dilihat pada Tabel 2.

Tabel 2: Perbandingan Total Biaya Keseluruhan

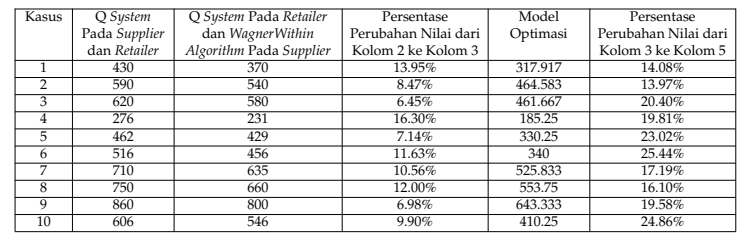

Pada penelitian ini dilakukan 3 uji sensitivitas pada Model Optimasi, yaitu:

1. Uji Sensitivitas Terhadap Nilai $c_{1}$ dan Total Biaya Rantai Pasok

2. Uji Sensitivitas Terhadap Nilai $c_{2}$ dan Total Biaya Rantai Pasok

3. Uji Sensitivitas Terhadap Periode Pengiriman dan Total Biaya Rantai Pasok

Hasil perhitungan sensitivitas dapat dilihat pada Tabel 3 hingga Tabel 5 dan Gambar 3 hingga Gambar 5.
Tabel 3: Perubahan Nilai $c_{1}$ dan Total Biaya Rantai Pasok

\begin{tabular}{|c|c|c|c|}
\hline Perubahan & Gradien & $c_{1}(\$)$ & $\begin{array}{c}\text { Total Biaya Rantai } \\
\text { Pasok }(\$)\end{array}$ \\
\hline-2 & 4 & 10 & 332 \\
\hline-1.9 & 4 & 10.1 & 332.8 \\
\hline-1.7 & 4 & 10.3 & 333.2 \\
\hline-1.6 & 4 & 10.4 & 333.6 \\
\hline-1.5 & 4 & 10.5 & 334 \\
\hline-1.4 & 4 & 10.6 & 334.4 \\
\hline-1.3 & 4 & 10.7 & 334.8 \\
\hline-1.2 & 4 & 10.8 & 335.2 \\
\hline-1.1 & 4 & 10.9 & 335.6 \\
\hline-1 & 4 & 11 & 336 \\
\hline-0.9 & 4 & 11.1 & 336.4 \\
\hline-0.8 & 4 & 11.2 & 336.8 \\
\hline-0.7 & 4 & 11.3 & 337.2 \\
\hline-0.6 & 4 & 11.4 & 337.6 \\
\hline-0.5 & 4 & 11.5 & 338 \\
\hline-0.4 & 4 & 11.6 & 338.4 \\
\hline-0.3 & 4 & 11.7 & 338.8 \\
\hline-0.2 & 4 & 11.8 & 339.2 \\
\hline-0.1 & 4 & 11.9 & 339.6 \\
\hline 0 & 0 & 12 & 340 \\
\hline
\end{tabular}

Pada Model Optimasi, dilakukan penyelesaian kasus yang melibatkan 2 hingga 10 retailer dengan periode pengiriman 12 bulan. Hasil komputasi dapat dilihat pada Tabel 6 dan Tabel 7.

Tabel 4: Perubahan Nilai $c_{2}$ dan Total Biaya Rantai Pasok

\begin{tabular}{|c|c|c|c|}
\hline Perubahan & Gradien & $c_{2}(\$)$ & $\begin{array}{c}\text { Total Biaya Rantai } \\
\text { Pasok }(\$)\end{array}$ \\
\hline-2 & 4 & 18 & 332 \\
\hline-1.9 & 4 & 18.1 & 332.4 \\
\hline-1.8 & 4 & 18.2 & 332.8 \\
\hline-1.7 & 4 & 18.3 & 333.2 \\
\hline-1.6 & 4 & 18.4 & 333.6 \\
\hline-1.5 & 4 & 18.5 & 334 \\
\hline-1.4 & 4 & 18.6 & 334.4 \\
\hline-1.3 & 4 & 18.7 & 334.8 \\
\hline-1.2 & 4 & 18.8 & 335.2 \\
\hline-1.1 & 4 & 18.9 & 335.6 \\
\hline-1 & 4 & 19 & 336 \\
\hline-0.9 & 4 & 19.1 & 336.4 \\
\hline-0.8 & 4 & 19.2 & 336.8 \\
\hline-0.7 & 4 & 19.3 & 337.2 \\
\hline-0.6 & 4 & 19.4 & 337.6 \\
\hline-0.5 & 4 & 19.5 & 338 \\
\hline-0.4 & 4 & 19.6 & 338.4 \\
\hline-0.3 & 4 & 19.7 & 338.8 \\
\hline-0.2 & 4 & 19.8 & 339.2 \\
\hline-0.1 & 4 & 19.9 & 339.6 \\
\hline 0 & 0 & 20 & 340 \\
\hline & & & \\
\hline
\end{tabular}

Tabel 6 menunjukkan hasil komputasi waktu run Model Optimasi, sedangkan Tabel 7 menunjukkan hasil komputasi waktu crash Model Optimasi. 


\section{Analisis}

Pada Q System dilakukan perhitungan optimal oleh masingmasing pihak. Hasil optimal yang didapatkan kemudian dijumlahkan untuk mendapatkan total biaya rantai pasok. Total biaya tersebut belum tentu optimal. Berdasarkan kenyataan, supplier tidak memiliki permintaan yang konstan dikarenakan permintaan pada supplier didapatkan dari penjumlahan pesanan dari beberapa retailer pada periode tertentu. Dapat dikatakan bahwa permintaan supplier bersifat lumpy. Tetapi jika menggunakan Q System, permintaan supplier diasumsikan konstan. Hal ini dikarenakan permintaan yang masuk ke supplier merupakan total dari seluruh permintaan retailer pada periode waktu tertentu, dalam penelitian ini 12 bulan. Contoh hasil perhitungan Q System pada contoh kasus dapat dilihat pada Gambar 6.

Tabel 5: Perubahan Periode Pengirimandan Total Biaya Rantai Pasok

\begin{tabular}{|c|c|c|}
\hline Periode & Total Biaya Rantai Pasok (\$) & Gradien \\
\hline 3 & 369 & -29.000 \\
\hline 4 & 340 & 7.000 \\
\hline 6 & 354 & -2.333 \\
\hline 12 & 340 & \\
\hline
\end{tabular}

Meskipun terlihat pada Gambar 6 bahwa permintaan retailer tidak dapat dipenuhi oleh supplier, tetapi jika dilakukan perhitungan tingkat permintaan pada pihak supplier dan retailer diketahui bahwa tingkat permintaan pihak supplier memenuhi tingkat permintaan pihak retailer 1 dan retailer 2 pada tiap periode. Hal ini terlihat dapat dilihat pada Tabel 8.

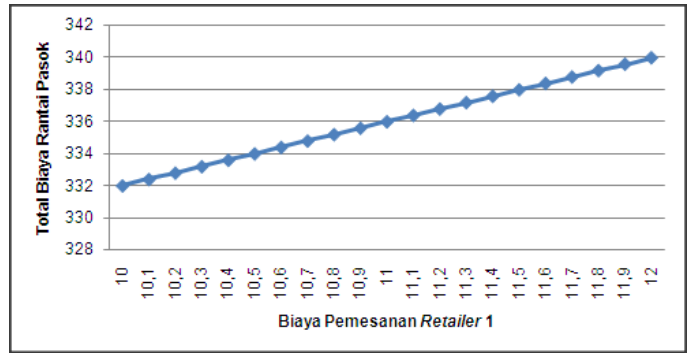

Gambar 3: Grafik Perubahan Nilai $c_{1}$ dan Total Biaya Rantai Pasok

Pada WagnerWithin Algorithm, perhitungan pada retailer dilakukan dengan menggunakan Q System. Karena diasumsikan bahwa permintaan retailer bersifat konstan, maka Q System merupakan metode perhitungan total biaya persediaan tradisional bagi retailer yang optimal. Data retailer yang didapatkan dari hasil perhi- tungan tersebut kemudian dimasukkan dalam perhitungan total biaya supplier dengan menggunakan WagnerWithin Algorithm.

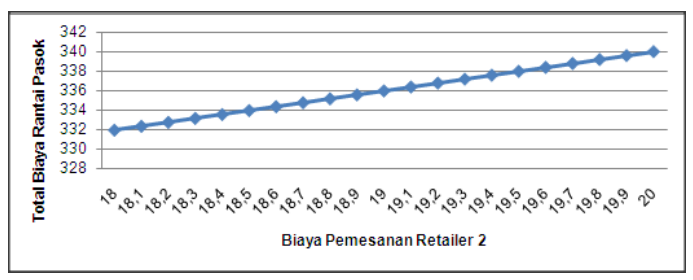

Gambar 4: Grafik Perubahan Nilai $c_{2}$ dan Total Biaya Rantai Pasok

Supplier menggunakan WagnerWithin Algorithm dikarenakan permintaan yang masuk pada supplier bersifat lumpy, dimana tiap bulan supplier harus mengirim barang ke semua retailer dengan jumlah yang berbedabeda tiap bulannya berdasarkan hasil perhitungan Q System yang dilakukan oleh tiap retailer. Hal ini sesuai dengan situasi nyata, dimana supplier harus memperhitungkan jumlah pengiriman yang sesuai untuk memenuhi permintaan retailer tiap bulan agar retailer tetap mau memesan pada supplier. Selain itu, WagnerWithin Algorithm merupakan metode heuristik yang paling efisien (menghasilkan total biaya persediaan paling kecil) dibanding metode lainnya. Tidak seperti Model Optimasi, WagnerWithin Algorithm dapat digunakan untuk kasus dengan 7 retailer atau lebih.

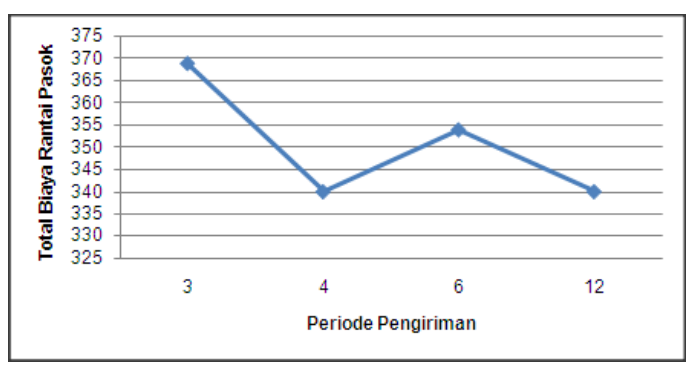

Gambar 5: Grafik Perubahan Periode Pengiriman dan Total Biaya Rantai Pasok

Pada Model Optimasi, keputusan akan diambil oleh supplier berdasarkan data yang diberikan oleh seluruh retailer. Hal ini dikarenakan Model Optimasi dirancang untuk permasalahan VMI (Vendor Managed Inventory), dimana supplier adalah pengambil keputusan bagi kedua belah pihak (pihak supplier maupun pihak retailer). Pada tahap perancangan model dilakukan penentuan parameter, variabel keputusan, fungsi tujuan dan koefisien pembatas.

Parameter yang digunakan adalah total biaya rantai pasok yang dihasilkan model optimasi lebih kecil dari pada metode lain (Q Sys- 
Tabel 6: Hasil Komputasi Waktu Run Model Optimasi

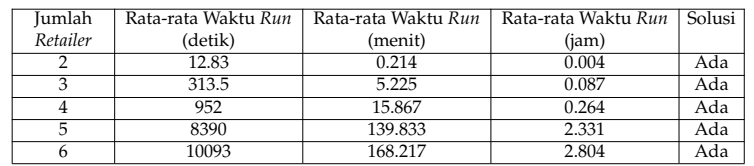

tem dan WagnerWithin Algorithm). Model yang dirancang merupakan model VMI (Vendor Managed Inventory) yang melihat total biaya yang dibebankan kepada pihak supplier dan retailer dimana diinginkan bahwa total biaya yang dihasilkan model lebih kecil dari pada total biaya yang dihasilkan oleh metode Q System dan WagnerWithin Algorithm. Variabel keputusan yang digunakan adalah jumlah inventory $\left(P_{t}\right.$, $\left.p_{i t}\right)$, jumlah pemesanan $\left(Q_{t}, q_{i t}\right)$ dan keputusan pemesanan $\left(Y_{t}, y_{i t}\right)$. Hal ini dikarenakan untuk mengetahui biaya penyimpanan perlu diketahui jumlah inventory dan untuk mengetahui biaya pemesanan perlu diketahui jumlah pemesanan optimal beserta kapan pemesanan optimal dilakukan. Fungsi tujuan pada penelitian ini adalah meminimasi total biaya rantai pasok yang terdiri dari biaya penyimpanan dan biaya pemesanan yang dibebankan kepada pihak supplier dan retailer. Koefisien pembatas merupakan batasanbatasan yang digunakan pada model optimasi yang disesuaikan dengan kendala pada kasus nyata. Oleh karena itu model dapat dikatakan valid.

Tabel 7: Hasil Komputasi Waktu Crash Model Optimasi

\begin{tabular}{|c|c|c|c|c|}
\hline $\begin{array}{c}\text { Jumlah } \\
\text { Retailer }\end{array}$ & $\begin{array}{c}\text { Rata-rata Waktu } \\
\text { Crash }(\text { detik) }\end{array}$ & $\begin{array}{c}\text { Rata-rata Waktu } \\
\text { Crash } \text { (menit) }\end{array}$ & $\begin{array}{c}\text { Rata-rata Waktu } \\
\text { Crash (jam) }\end{array}$ & Solusi \\
\hline 7 & 7451 & 124.183 & 2.070 & Tidak Ada \\
\hline 8 & 5688 & 94.800 & 1.580 & Tidak Ada \\
\hline 9 & 5388 & 89.800 & 1.497 & Tidak Ada \\
\hline 10 & 3268 & 54.467 & 0.908 & Tidak Ada \\
\hline
\end{tabular}

Ada 3 batasan yang digunakan, yaitu: inventory balanced constraint (10) dan (13), binary constraint (11), (12), (14) dan (15) serta non-negativity constraint (16). Inventory balanced constraint digunakan karena sesuai dengan kenyataan bahwa jumlah inventory pada tiap periode bergantung pada jumlah inventory diperiode sebelumnya, jumlah barang yang dipesan pada periode yang bersangkutan serta jumlah permintaan pada periode tersebut. Binary constraint digunakan untuk menentukan kapan terjadi pemesanan dimana constraint ini akan bernilai 1 ketika pada periode tersebut terjadi pemesanan dan bernilai 0 ketika pada periode tersebut tidak terjadi pemesanan. Non-negativity constraint digunakan karena sesuai dengan kenyataan bahwa jumlah inventory dan jumlah barang yang dipesan tidak akan bernilai negatif. Jika ada jumlah inventory yang bernilai negatif maka dapat dikatakan telah terjadi stock out. Pada penelitian ini tidak diperhitungkan mengenai stock out.

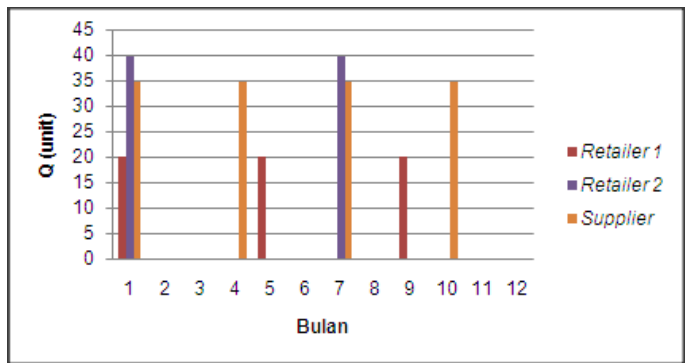

Gambar 6: Grafik Perhitungan Q System Pada Contoh Kasus

Model yang telah dibuat kemudian diterjemahkan kedalam bahasa pemrograman AMPL dan kemudian diselesaikan dengan menggunakan program NEOS yang dapat diakses pada websitehttp://www.neosserver.org/neos/solvers/milp:MINTO/AMPL. htmldengan memasukkan data AMPL yang telah dibuat. AMPL merupakan bahasa pemograman yang ringkas sehingga digunakan pada penelitian ini. Penelitian ini juga menggunakan program NEOS dikarenakan program tersebut mudah digunakan dan mudah diakses oleh pengguna.

Tabel 8: Tingkat Permintaan Pihak Supplier dan Retailer

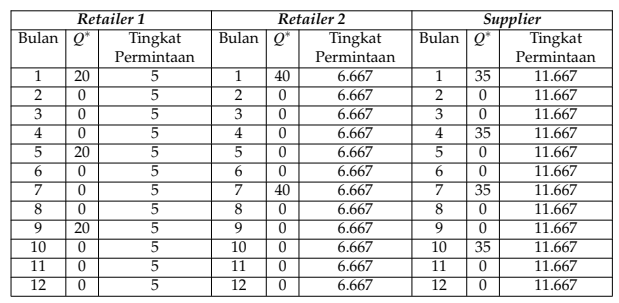

Model Optimasi memiliki kelemahan dimana model tidak dapat digunakan untuk supplier yang memiliki 7 atau lebih retailer dengan periode waktu pengiriman 12 bulan. Hal ini dikarenakan batasan program. Oleh karena itu, untuk kasus tersebut dapat digunakan perhitungan lain seperti WagnerWithin Algorithm. Lama penyelesaian kasus tergantung dari memori yang dibutuhkan oleh program NEOS dalam penyelesaian. Semakin banyak data yang diinput, semakin banyak pula memori yang dibutuhkan. Oleh karena itu, semakin bertambah jumlah retailer yang diuji, semakin lama waktu yang dibutuhkan untuk penyelesaiannya. Pada penyelesaian 7 hingga 10 retailer, memori yang 
dibutuhkan sudah melebihi kapasitas program sehingga program tidak dapat menyelesaikan kasus tersebut. Semakin banyak data yang diinput, semakin cepat waktu yang dibutuhkan software untuk menjadi crash.

Biaya pemesanan retailer pada VMI (Vendor Managed Inventory) lebih kecil dari pada Q System. Hal ini dikarenakan pada VMI (Vendor Managed Inventory), retailer hanya dikenakan biaya penyaluran informasi yang berisi datadata yang dimiliki oleh retailer dan biaya transportasi sedangkan pada $\mathrm{Q}$ System, retailer dikenakan biaya telepon, biaya fax, biaya penyaluran informasi, biaya transportasi, biaya penerimaan dan pemeriksaan material, biaya administrasi yang berhubungan dengan transaksi pembelian, dan lain-lain. Pada penelitian ini, biaya pemesanan retailer yang digunakan dalam perhitungan merupakan biaya pemesanan dalam Q System. Oleh karena itu dapat dikatakan bahwa total biaya rantai pasok Model Optimasi sesungguhnya lebih kecil lagi dibandingkan dengan total biaya yang didapatkan pada perhitungan. Hal tersebut telah dibuktikan dengan melakukan uji sensitivitas.

\section{Kesimpulan}

Berdasarkan hasil perancangan, pegujian dan analisis yang dilakukan pada model dapat disimpulkan bahwa model optimasi yang dikembangkan merupakan model optimasi untuk meminimasi total biaya rantai pasok yang terdiri dari biaya di sisi supplier dan retailer yang melibatkan biaya penyimpanan dan biaya pemesanan. Solusi yang dihasilkan model optimasi lebih baik dibandingkan solusi yang dihasilkan oleh Q System maupun WagnerWithin Algorithm. Model yang dikembangkan telah valid dikarenakan batasanbatasan yang digunakan pada model sesuai dengan kendala yang ada pada kasus nyata. Batasan tersebut dapat diklasifikasi menjadi 3 jenis, yaitu: inventory balanced constraint, binary constraint serta nonnegativity constraint. Saransaran yang dapat diberikan untuk pengembangan penelitian ini antara lain: Model Optimasi yang telah dirancang dapat diverifikasi dengan menguji model pada kasus nyata yang sederhana. Selain itu, model optimasi dapat dikembangkan sehingga dapat digunakan untuk kasus yang memiliki 7 retailer atau lebih dengan periode waktu 12 bulan. Penelitian ini dapat dikembangkan lebih lanjut untuk masalah negosiasi antara pihak supplier dan pihak retailer dalam pembagian keuntungan total biaya rantai pasok.

\section{Daftar Pustaka}

Disney, S. M. dan Towill, D. R. 2003, VendorManaged Inventory and Bullwhip Reduction in a TwoLevel Supply Chain. International Journal of Operations \& Production Management, vol. 23, iss. 5 , p. 625651.

Fogarty, Donald W., Blackstone dan Thomas R. Hoffman. 1991, Production and Inventory Management, 2nd edition, South Western Publishing, Cincinnati.

Hartini, Sri dan Kamal, Andre S. 2010, Penentuan Kebijakan Pemenuhan Pesanan dengan Model Vendor Managed Inventory. Jurnal Teknik Industri, vol. 11, no. 2, Agustus 2010, p. 95100

http://jobs.indonetasia.com/id/lowongankerja-sma-pt-nutrifood-indonesia/ [2013, 3 Januari]

http:/ / www.neosserver.org/neos/solvers/milp: MINTO/AMPL.html [2013, 6 Desember]

http:/ / www.waytodeal.com/web/ultrajaya/about [2013, 3 Januari]

Indrajit, Richardus Eko dan Djokopranoto, Richardus. 2002, Konsep Manajemen Supply Chain: Cara Baru Memandang Mata Rantai Penyediaan Barang, Grasindo, Jakarta.

Kim, Bowon dan Park, Chulsoon. 2010, Supply Chain Coordination between Supplier and Retailer in a VMI (VendorManaged Inventory) Relaitonship. The Business Review, Cambridge, vol. 15, no. 2, Summer 2010, p. 165170.

Savasaneril, Secil dan Erkip, Nesim. 2010, An Analysis of Manufacturer Benefits Under Vendor Managed Systems. IIE Transactions, vol. 42, no. 7, Juli 2010, p.455 477.

Simchi Levi, D., Kaminsky, P., dan Simchi Levi, E. 2000, Designing and Managing The Supply Chain: Concepts, Strategies, and Case Studies, 1st edition, McGraw-Hill, New York.

Tersine, Ricahrd J. 1994, Principles Of Inventory and Materials Management, 4thedition, Prentice Hall, New Jersey.

Yao, Y., Dong, Y., dan Dresner, Martin E. 2007, Analizing InformationEnabled Stockout Management Under VendorManaged Inventory. Inf Thecnol Manage, vol. 8, p. 133145. 
Yao, Y., Evers, Philip T., dan Dresner, Martin E. 2007, Supply Chain Integration In VendorManaged Inventory. Decision Support Systems, 43, p. 663674 . 